\title{
Genetic aspects of the technological and eating qualities of pig meat
}

\author{
P. SELLIER \\ Institut National de la Recherche Agronomique, Station de Génétique quantitative \\ et appliquée, 78350 Jouy-en-Josas
}

A survey of the genetics of meat quality in pigs is presented. Genetic effects play a primary role in the overall variation of the technological and eating qualities of pig meat and our present knowledge may be summarized as follows.

(1) The halothane sensitivity gene, in the homozygous state, induces a very fast fall of muscle $\mathrm{pH}$ and is directly responsible for the PSE (pale, soft, exudative) meat condition. It explains to a large extent the genetic variation in technological qualities (drip loss, processing yields) and also in eating qualities (especially tenderness) of pig meat.

(2) It may be admitted that the halothane sensitivity gene is almost completely recessive as regards its effect on meat quality, though certain results do not support this assumption.

(3) The breed variation in pork technological qualities partly results from the large breed differences in halothane gene frequency, but other factors are implied, particularly those which affect meat ultimate $\mathrm{pH}$. One example is the so-called "Hampshire effect " which leads to the " acid meat" condition and could be due to a single dominant gene (RN-) : the latter point however awaits confirmation.

(4) In addition to the halothane sensitivity gene, an important factor responsible for the breed variation in pork eating quality is the intramuscular fat content.

(5) The heritability of technological quality criteria $(\mathrm{pH}$, reflectance, ...) is of moderate magnitude $(0.20$ to 0.30$)$, whereas that of intramuscular fat content is higher $(0.40$ to 0.50$)$.

(6) A genetic antagonism, more or less marked according to the populations and the traits involved, exists between pork technological quality and growth or body composition traits. The halothane sensitivity gene is the major factor responsible for the "meat quantity-meat quality » genetic antagonism, since its effect is unfavourable on meat quality while favourable on carcass lean content.

(7) The within-breed genetic relationship seems to be of rather low magnitude between intramuscular fat content and carcass fatness.

\section{Influence of halothane sensitivity and ultimate pH on meat quality in three pig breeds}

\author{
P. SELLIER ${ }^{(1)}$, G. MONIN ${ }^{(2)}$, A. TALMANT ${ }^{(2)}$, \\ B. JACQUET ${ }^{(3)}$, J.P. RUNAVOT ${ }^{(4)}$
}

(1) Institut National de la Recherche Agronomique, Station de Génétique quantitative et appliquée, 78350 Jouy-en-Josas

(2) Institut National de la Recherche Agronomique, Station de Recherches sur la Viande, Theix 63122 Ceyrat

(3) Centre Technique de la Salaison, de la Charcuterie et des Conserves de Viande, 94700 Maisons-Alfort

(4) Institut Technique du Porc, Pôle Amélioration de l'Animal, B.P. 3, 35650 Le Rheu

The technological qualities of the meat from 45 Large-White (LW), 42 Pietrain (P) and 58 Belgian Landrace (BL) purebred pigs were assessed by fresh meat measurements and cooked "Paris ham " processing ability. There were 9 halothane-negative (HN) and 33 Halothane positive (HP) animals among $\mathrm{P}$ pigs, $16 \mathrm{HN}$ and $42 \mathrm{HP}$ among $\mathrm{BL}$ pigs, whereas all the $\mathrm{LW}$ pigs were HN. Glycolytic potential and a number of enzyme activities of three muscles of various metabolic types where measured on a subsample of 101 pigs $(28 \mathrm{LW}, 30 \mathrm{P}, 43 \mathrm{BL})$. As a general rule, the 
traits under study were much more affected by breed than by halothane phenotype. Regarding breed differences, the results may be summarized as follows :

1 - The LW breed, free from Halothane sensitivity, exhibits a relatively slow pH fall and gives meat with the most satisfying technological qualities.

2 - The $\mathrm{P}$ breed combines a low $\mathrm{pH} 1$ (due to the high incidence of HP animals) with a rather low ultimate $\mathrm{pH}$ (presumably due to a slightly higher muscle glycolytic potential). Since the post-mortem acidification of muscle tissue takes place at a fast rate and has a relatively large extent, the meat from $\mathrm{P}$ pigs presents the worst technological qualities.

3 - In the BL breed, the unfavorable effects of halothane sensitivity are counterbalanced to some extent by the maintaining of ultimate $\mathrm{pH}$ at a higher level than in the two other breeds in most muscles studied : BL pigs are consequently intermediate between LW and $\mathrm{P}$ in meat quality.

\title{
Genetic parameters of some meat quality traits in the Large-White, French Landrace and Belgian Landrace pig breeds
}

\author{
G. COLE ${ }^{(1)}$, Geneviève LE HENAFF ${ }^{(2)}$, P. SELLIER ${ }^{(2)}$
}

(1) Department of Animal Science, Njala University College, Freetown, Sierra Leone (2) Institut National de la Recherche Agronomique, Station de Recherches de Génétique quantitative et appliquée, 78350 Jouy-en-Josas

This analysis deals with data collected between 1974 and 1986 in central progeny-test stations on 8867 Large-White (LW), 4098 French Landrace (FL) and 2840 Belgian Landrace (BL) female pigs, slaughtered at $100 \mathrm{~kg}$ liveweight. The meat quality traits involved in this study are : subjective score (SS), ultimate $\mathrm{pH}$ of the Adductor femoris muscle ( $\mathrm{pHu}$ ), reflectance of the Gluteus superficialis muscle (Ref), water holding capacity (imbibition time) of the Biceps femoris muscle (WHC) and meat quality index (MQI) combining $\mathrm{pHu}$, Ref and WHC and predicting the technological yield of cooked "Paris ham" processing. Meat quality traits are expressed as deviations from the "slaughter day" average whereas growth and body composition traits are expressed as deviations from the "batch" average. Heritabilities (h2) and genetic correlations (rA) are estimated from the sire variance and covariance components, separately for each breed (2483, 1123 and 493 sires in LW, FL and BL breeds, respectively). Genetic correlations between average daily gain (ADG) and meat quality traits are generally unfavorable in the LW breed (c.g. $\mathrm{rA}=-0.27 \pm 0.09$ for $\mathrm{SS}$ and $\mathrm{ADG}$, and $\mathrm{rA}=-0.32 \pm 0.13$ for MQI and ADG), whereas they are of much lower magnitude in the FL and the BL breeds. Genetic correlations between estimated carcass lean content (ECLC) and meat quality traits are mostly unfavorable : the genetic antagonism between meat quantity and meat quality appears to be stronger in the BL than in the LW breed (e.g. $\mathrm{rA}=-0.53 \pm 0.20$ vs $\mathrm{rA}=-0.32 \pm 0.08$ for SS and ECLC, and $\mathrm{rA}=-0.28 \pm 0.20$ vs $\mathrm{rA}=-0.16 \pm 0.10$ for MQI and ECLC).

\section{Lipids and qualities of pork adipose and muscular tissues. Factors of variation. 1rst Part : Lipids and qualities of adipose tissue. Factors of variation}

\author{
J.P. GIRARD ${ }^{(1)}$, Josiane BOUT ${ }^{(2)}$, Dominique SALORT ${ }^{(2)}$
}

(1) Institut National de la Recherche Agronomique, Station de Recherches sur la Viande, Theix 63122 Ceyrat

(2) Institut Technique du Porc, B.P. 3, 35650 Le Rheu

The three main components of fatty tissues are: water, proteins and lipids. The latter, because of their effect on quality, are generally divided, into glycerol fatty acid esters and the unsaponifiable fraction with pigments and steroids. 